\title{
Field experience of Fluoride Nilogon: a method of fluoride removal from groundwater
}

\author{
Rajkamal Mohan, Sweety Gogoi, Anup J. Bora, Gautam Baruah, \\ Shreemoyee Bordoloi, Asadulla A. Ali, Hridip R. Sarma and Robin K. Dutta* \\ Department of Chemical Sciences, Tezpur University, Napaam 784 028, India
}

Field trial of a patented fluoride removal method, based on precipitation-adsorption, has been carried out in some villages of Assam, North East India, with groundwater sources containing $1.8-20 \mathrm{mg} / \mathrm{l}$ initial $\left[\mathrm{F}^{-}\right]$at small community (220 l) and household (15 l) levels. Pre-acidified water containing $0.68 \mathrm{mM}$ phosphoric acid was treated in a crushed limestone bed (1-20 $\mathrm{mm})$ for $3 \mathrm{~h}$ and filtered through a sand-gravel filter to retain a desired $0.7 \mathrm{mg} / \mathrm{l}\left[\mathrm{F}^{-}\right]$with $\mathrm{pH}$ of 7.44 7.9 and relevant water quality parameters meeting WHO guidelines. A slightly higher dose can totally remove fluoride. The fluoride removal has been found to be independent of initial $\left[\mathrm{F}^{-}\right]$. The units have been showing consistent results till now for over five and half years and 4625 batches of use without requiring any interventions like reactivation, replacement or replenishment of the limestone bed. With consistent removal of fluoride from any initial concentration to a desired concentration, a recurring cost of only Rs $0.005 / 1$ of water and an estimated life of the limestone bed of about 50 years or 39,000 batches, this safe, environment-friendly and simple method without requiring electricity, has been gaining popularity as Fluoride Nilogon.

Keywords: Fluoride removal, groundwater, hydroxyapatite, limestone defluoridation, phosphoric acid.

FLUORIDE, a naturally occurring mineral, is essential in small quantities for proper growth and maintenance of teeth and bones in humans. However, its excess consumption causes irreversible damage to teeth and bones, a phenomenon known as dental and skeletal fluorosis ${ }^{1}$. Other effects such as osteoporosis, arthritis, braindamage, cancer and neurological disorders in human and certain health problems in animals are seen due to excess fluoride comsumption ${ }^{1-3}$. Fluoride contamination in groundwater occurs due to geological factors such as dissolution of rocks like fluorite, biotite, topaz, etc. and anthropogenic activities like industrial effluents ${ }^{4}$. Over 200 million people from India, China, Sri Lanka and the Rift Valley nations in Africa are affected by excess fluoride poison-

*For correspondence. (e-mail: robind@tezu.ernet.in) $\mathrm{ing}^{2}$. In India, groundwater of many states are fluorideaffected $^{5}$. In Assam, North East India, large areas of East Karbi Anglong and Hojai district and some parts in neighbouring areas of Guwahati city are affected by excess fluoride in groundwater ${ }^{6,7}$. The World Health Organization (WHO) prescribes a guideline value of $1.5 \mathrm{mg} / \mathrm{l}$ for fluoride in drinking water ${ }^{2}$. However, the Bureau of Indian Standards (BIS) has set a lower permissible limit of $1.0 \mathrm{mg} / 1$ for fluoride ${ }^{8}$.

Research is ongoing to develop a suitable method for removal of difficult-to-remove fluoride with high efficiency and low cost, while at the same time the method has to be safe, environment-friendly and easy to operate by a layman ${ }^{9-11}$. Researchers have developed several defluoridation techniques to mitigate fluoride contamination, viz. coagulation-precipitation ${ }^{12}$, reverse osmosis ${ }^{13}$, electro-coagulation ${ }^{14}$, nanofiltration ${ }^{15}$, ion exchange ${ }^{16}$, adsorption ${ }^{17,18}$, etc. The Nalgonda technique, based on the coagulation-precipitation technique, was once widely used in India. Now it is losing popularity due to difficulty in $\mathrm{pH}$ adjustment, high residual sulphate and aluminium in treated water ${ }^{14}$.

Adsorption is one of the most common methods of fluoride removal due to its effectiveness, relatively low cost and easy operation. Several adsorbent materials have been reported for fluoride removal from water, e.g. limestone (calcite) ${ }^{19-21}$, hydroxyapatite ${ }^{19}$, quartz ${ }^{19}$, bauxite ${ }^{22}$, gypsum $^{22}$, brushite ${ }^{23}$, laterite ${ }^{24}$, pumice stone ${ }^{25}$, rare earth oxides $^{26}$, graphene ${ }^{27}$, chitosan ${ }^{28}$, activated alumina ${ }^{29}$, al$\mathrm{um}^{30}$, and calcined phosphoric acid (PA)-treated lime ${ }^{31}$. Reardon and $\mathrm{Wang}^{32}$, reported a combined precipitation and adsorption method where $\mathrm{CO}_{2}$ is passed through fluoride-contaminated water in a limestone bed column for generating $\mathrm{Ca}^{2+}$ ions for precipitation of $\mathrm{CaF}_{2}$. However, handling of $\mathrm{CO}$ canisters is not easy for rural applications. Several interesting studies were conducted subsequently by adding other acids to the influent water, before treatment with crushed limestone, where fluoride was removed by both precipitation of fluorite and adsorption of fluoride on limestone surface ${ }^{21,33-37}$. However, fluoride removal by these methods is associated with one or more shortcomings, such as high operational and maintenance costs, low capacity of adsorbent, frequent replacement of parts and involving energy-intensive steps ${ }^{34}$. 
Recently, a highly efficient, low-cost, safe and environment-friendly method of fluoride removal, viz. phosphoric acid-crushed limestone treatment (PACLT), had been patented and reported by our research group ${ }^{38,39}$. In this method, water is pre-mixed with $0.01 \mathrm{M} \mathrm{PA}$ and then treated in a crushed limestone fixed-bed reactor working in a plug-flow (batch) mode for $3 \mathrm{~h}$. Precipitation of $\mathrm{CaF}_{2}$, fluorapatite (FAP), and physisorption of fluoride by hydroxyapatite (HAP) formed in situ from the reaction between calcium and phosphate ions in the reactor were found to be the dominant mechanisms for fluoride removal in this method ${ }^{38}$. Since a bench-scale pilot test of the method using synthetic fluoridecontaining water had shown it to have high potential for practical applications ${ }^{38}$, we had decided to conduct a field trial.

Here we present results of the field trial of the PACLT method at a small community scale and household level in some fluoride-affected villages of East Karbi Anglong district. The dose of PA was optimized using fluoride containing natural feed water collected from one of the field sources to remove excess fluoride and retaining about $0.6 \mathrm{mg} / \mathrm{l}$ fluoride in the treated water. The performance of the field units was pre-assessed with a small replica of the field unit set-up in the laboratory using feed water collected from the field source. The results of the field trial, its safety and suitability have been discussed.

The field trial has already completed over five and half years, but the units are still working well. The method has already started gaining popularity as Fluoride Nilogon (nilogon meaning removal in Assamese). Despite using for total of 4625 batches (once or twice a day) and even for water with initial fluoride $\left(\left[\mathrm{F}^{-}\right]_{0}\right)$ as high as $20 \mathrm{mg} / \mathrm{l}$, none of the limestone beds has been exhausted yet, making it impossible for us to carry out a study of regeneration of the limestone bed. The excellent experience of the field trial prompted us to publish the results without waiting for exhaustion of the limestone to facilitate use of this rural technology for the benefit of the needy at the earliest.

\section{Materials and methods}

\section{Materials}

Limestone used in the field trial was obtained as a gift from Bokajan Cement Factory, Cement Corporation of India, Bokajan, Karbi Anglong. The limestone sample with density $2.59 \mathrm{~g} / \mathrm{cm}^{3}$ was high-purity calcite as evident from chemical composition and XRD analysis ${ }^{36}$. The crude limestone was crushed and segregated to selected chip sizes before use. For dose-optimization experiments, the fluoride stock solution was prepared by dissolving $\mathrm{NaF}$ (AR-grade, Merck, Mumbai) in doubly distilled water. Synthetic fluoride containing groundwater was prepared by spiking tap water with fluoride from the stock solution. The composition of the synthetic groundwater was: $\mathrm{pH}(7.47), \mathrm{Na}^{+}(60.60 \mathrm{mg} / \mathrm{l}), \mathrm{K}^{+}(1.07 \mathrm{mg} / \mathrm{l})$, $\mathrm{Ca}^{2+}(2.50 \mathrm{mg} / \mathrm{l}), \mathrm{Mg}^{2+}(2.40 \mathrm{mg} / \mathrm{l}), \mathrm{Hg}^{2+}(<0.001 \mathrm{mg} / \mathrm{l})$, $\mathrm{F}^{-}(0.20 \mathrm{mg} / \mathrm{l}), \mathrm{Cl}^{-}(5.4 \mathrm{mg} / \mathrm{l}), \mathrm{SO}_{4}^{2-}(6.3 \mathrm{mg} / \mathrm{l}), \mathrm{PO}_{4}^{3-}$ $(0.70 \mathrm{mg} / \mathrm{l})$, hardness as $\mathrm{CaCO}(80 \mathrm{mg} / \mathrm{l})$ and alkalinity as $\mathrm{CaCO}(86 \mathrm{mg} / \mathrm{l})$. Analytical-grade PA (Merck, Mumbai) was used in laboratory experiments. Food-grade 85\% PA (Lakshita Chemicals, Mumbai) was used in field trials.

\section{Field units}

One small community unit of 2201 capacity and five household units of 151 capacity each were used for the field trial in four different villages of East Karbi Anglong district (Supplementary Figures 1 and 2). The fluoride concentration in water of the selected field sources was found to be in the range $20.0-2.8 \mathrm{mg} / \mathrm{l}$. For the small community system, a 5001 plastic tank was used as the reactor chamber, whereas a 10001 plastic tank was used as the four-layered sand-crushed limestone-sand-gravel filter-cum-pH corrector. The reactor chamber filled with crushed limestone of size 1-20 mm gave a void volume of 2201 . An additional 5001 plastic tank was used to collect the fluoride-contaminated water supplied by the local public health water supply scheme. For household systems, a 401 bucket was used as the reactor chamber, containing limestone chips of the same size, giving a void volume of 151 (Supplementary Figure 2). A four-layered filter-cum-pH corrector was made with another 401 bucket (Supplementary Figure 2). A 151 bucket was used for mixing PA to the fluoride contaminated water and for feeding the reactor. However, it was observed later that a simple sand-gravel filter also gave the same result as that of the four-layered filters, and therefore the four-layered filters were replaced by simple sand-gravel filters for the other units installed in the villages.

\section{Dose optimization and pre-assessment of performance}

A small replica of the field units was set up in the laboratory for optimization of dose of PA and pre-assessment of the performance of the field units using feed water collected from the field water source of the small community unit. This groundwater supplied by the Public Health Engineering Department, Government of Assam, had fluoride concentration ranging between 5.0 and $4.6 \mathrm{mg} / \mathrm{l}$ during the year. Three low-density polyethylene containers were used as mixer, reactor and four-layered filtercum-pH corrector to make the replica unit (Supplementary Figure 3). 


\section{Procedure}

Fluoride-contaminated field water, after mixing with appropriate amount of PA, was fed to the reactor and kept for a residence time of $3 \mathrm{~h}$. After $3 \mathrm{~h}$, the water was transferred to the filter. The first time-treated water occupied the void volume of the filter-cum-pH corrector and therefore, fluoride-free water could only be collected from the second treatment onwards, thus allowing enough residence time for the treated water to finally settle with a $\mathrm{pH}$ of 7.44-7.90.

\section{Instrumental analysis}

The concentrations of fluoride in water were determined using an Orion Multiparameter Kit (Orion 5 Star, pHISE-Cond-DO Benchtop) using a fluoride ion selective electrode. Total ionic strength adjustment buffer (TISAB III) was used to control ionic strength and de-complex fluoride. The $\mathrm{pH}$ was determined using another Orion Multiparameter Kit with a $\mathrm{pH}$ electrode. The metal ions were determined using an atomic absorption spectrophotometer (AAS, Thermo iCE 3000 series, USA) fitted with a hydride vapour generator.

\section{Results and discussion}

\section{Laboratory study}

Optimization of PA dose: Defluoridation from groundwater with initial $4.8 \pm 0.2 \mathrm{mg} / \mathrm{l}$ fluoride, collected from field source, was examined with $0.001 \mathrm{M}[\mathrm{PA}]_{0}$ in the feed water to compare the results with those of the benchscale pilot test reported earlier with synthetic fluoride containing water ${ }^{38}$. Figure 1 shows the results of fluoride removal versus the number of batches of treatment $(n)$. The fluoride removal was found to be somewhat poor initially, which started to improve after ten batches and showed further improvement after 16 batches. The observed initial poor defluoridation may be attributed to possible presence of $\mathrm{CaO}$ impurity in the limestone. The $\mathrm{CaO}$ impurity may neutralize a part of PA, decreasing the effective concentration of PA for fluoride removal. The alkalinity (as $\mathrm{CaCO}_{3}$ ) in the field water was found to be $150 \mathrm{mg} / \mathrm{l}$ compared to $86 \mathrm{mg} / \mathrm{l}$ in the synthetic water used earlier. However, there was no noticeable change in defluoridation due to the higher alkalinity of field water compared to synthetic water. Similarly, there was no effect of presence of slightly higher concentrations of sulphate $(60 \mathrm{mg} / \mathrm{l})$ and chloride $(20 \mathrm{mg} / \mathrm{l})$ ions in field water compared those in the synthetic water $(6.3 \mathrm{mg} / \mathrm{l}$ and $5.4 \mathrm{mg} / \mathrm{l}$ respectively). During the bench-scale pilot tests, we observed good fluoride removal right from the first batch with a higher $[\mathrm{PA}]_{0}$ dosage of $0.01 \mathrm{M}$ to the feed ${ }^{38}$. Therefore, it was decided to pretreat the crushed lime- stone bed with $0.01 \mathrm{M}[\mathrm{PA}]_{0}$ before lowering the dose of feed PA to get a desirable effluent fluoride concentration of around $0.7 \mathrm{mg} / \mathrm{l}$ for healthy teeth and bones ${ }^{2}$.

In order to determine the optimum $[\mathrm{PA}]_{0}$ dose for field trial, fluoride was removed from the field water using the replica unit at different dose of $[\mathrm{PA}]_{0}$. For this experiment, a limestone bed of 10-15 mm chip size was first pretreated with $0.01 \mathrm{M}$ PA to neutralize any lime $(\mathrm{CaO})$ present with limestone, followed by defluoridation with varying doses of $[\mathrm{PA}]_{0}$ in the range $0.01-0.5 \mathrm{mM}$ in the feed field water; Figure 2 presents the results. It was observed that in the presence of $0.01 \mathrm{M}[\mathrm{PA}]_{0}$, fluoride was removed from 4.8 to $0.01 \mathrm{mg} / \mathrm{l}$, which is much below the prescription of WHO for drinking water. On lowering $[\mathrm{PA}]_{0}$ from $0.01 \mathrm{M}$ to $0.7 \mathrm{mM}$, the effluent $\left[\mathrm{F}^{-}\right]$increased from 0.01 to $0.41 \mathrm{mg} / \mathrm{l}$, still well below the prescription of WHO. On further reducing $[\mathrm{PA}]_{0}$ to $0.6 \mathrm{mM}$, the effluent

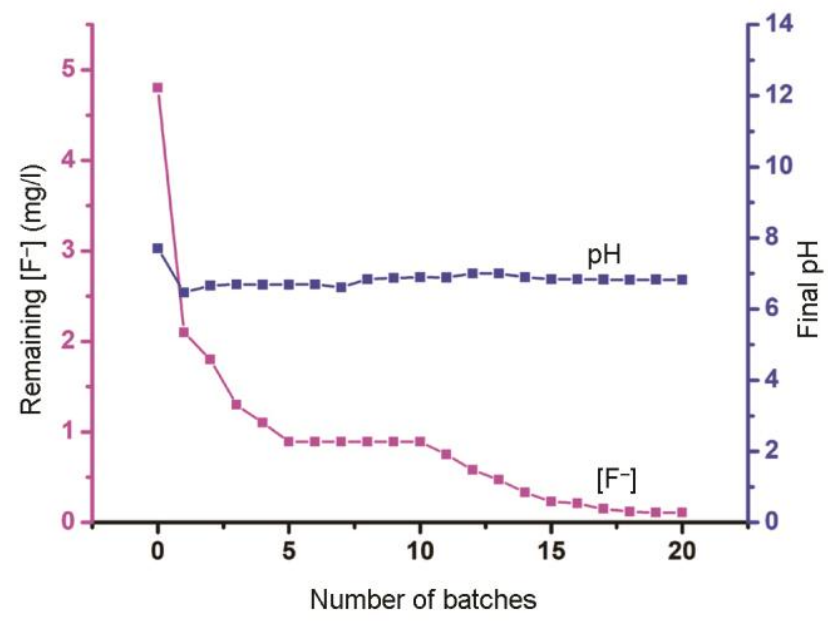

Figure 1. Plots of remaining $\left[\mathrm{F}^{-}\right]$with $\mathrm{pH}$ versus the number of batches used in PACLT for fluoride removal in the replica unit from field water with $0.001 \mathrm{M}[\mathrm{PA}]_{0} .\left[\mathrm{F}^{-}\right]_{0}=4.8 \pm 0.2 \mathrm{mg} / \mathrm{l}$.

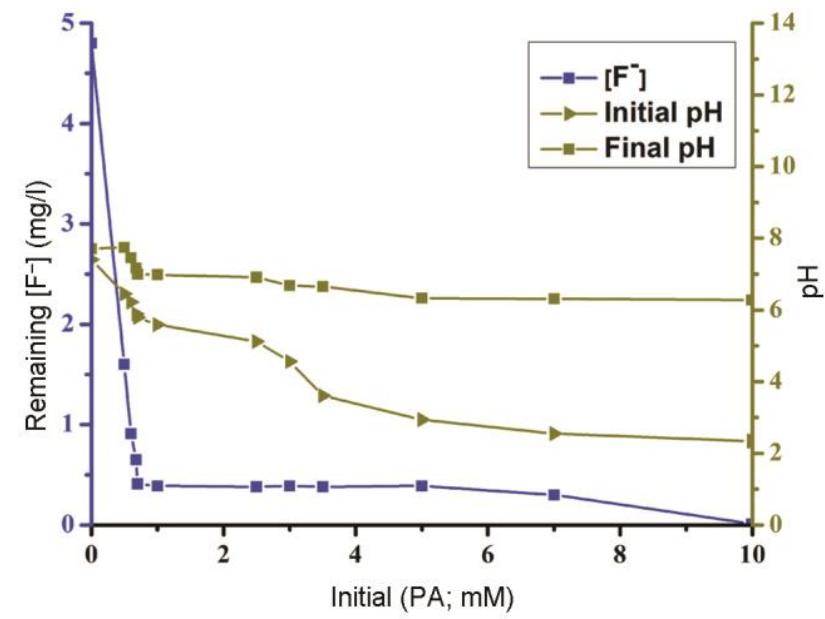

Figure 2. Plots of remaining $\left[\mathrm{F}^{-}\right]$and $\mathrm{pH}$ of water before $\left(\mathrm{pH}_{0}\right)$ and after $\left(\mathrm{pH}_{\mathrm{f}}\right)$ treatment in the presence of varying $[\mathrm{PA}]_{0}$ in the replica unit with field water having $4.8 \pm 0.2 \mathrm{mg} / 1$ of $\left[\mathrm{F}^{-}\right]_{0}$. 
$\left[\mathrm{F}^{-}\right]$increased to $0.91 \mathrm{mg} / \mathrm{l}$. Therefore, $[\mathrm{PA}]_{0}$ of $0.68 \mathrm{mM}$, which gave an effluent $\left[\mathrm{F}^{-}\right]$of $0.65 \mathrm{mg} / \mathrm{l}$, was chosen to be the optimum $[\mathrm{PA}]_{0}$ for field trials.

The $\mathrm{pH}$ of field water, before and after treatment with $[\mathrm{PA}]_{0}$ ranging from $0.01 \mathrm{M}$ to $0.5 \mathrm{mM}$ was measured (Figure 2). On decreasing $[\mathrm{PA}]_{0}$ from $0.01 \mathrm{M}$ to $0.68 \mathrm{mM}$, the initial $\mathrm{pH}$ of the feed water increased gradually from 2.34 to 5.89 . The $\mathrm{pH}$ of the treated water increased after treatment in the crushed-limestone reactor, which increased further after passing through the fourlayered sand-limestone-sand-gravel filter (Supplementary Figure 3 ). The effluent $\mathrm{pH}$ was below 6.5 with $[\mathrm{PA}]_{0}$ between $0.01 \mathrm{M}$ to $5.0 \mathrm{mM}$, which is lower than the minimum acceptable limit for drinking water, whereas it was above 6.5 with $[\mathrm{PA}]_{0}$ below $3.5 \mathrm{mM}$. On the other hand, effluent $\left[\mathrm{F}^{-}\right]$of $0.91 \mathrm{mg} / 1$ and higher was detected with $[\mathrm{PA}]_{0}$ of $0.6 \mathrm{mM}$ and below (with an initial $\mathrm{pH}$ of 6.22 and above). However, both desirable effluent $\left[\mathrm{F}^{-}\right]$of $0.65 \mathrm{mg} / \mathrm{l}$ and acceptable $\mathrm{pH}$ of 7.37 for drinking purpose were achieved with $[\mathrm{PA}]_{0}$ of $0.68 \mathrm{mM}$. Therefore, this optimum initial PA concentration was chosen for fixing the dose of $[\mathrm{PA}]_{0}$ for the field trial as $0.463 \mathrm{ml}$ of $8.5 \%$ PA per litre of water. However, for convenience of handling, rounded doses of $7 \mathrm{ml}$ and $102 \mathrm{ml}$ of $8.5 \%$ PA were used for 151 household and 2201 small community units respectively.

Pre-assessment of performance: For a quicker assessment of the performance of field units, we examined the performance of the replica unit in the laboratory using fluoride-contaminated groundwater collected from the field source (Supplementary Figure 3). The pre-acidified influent water was poured into the crushed limestone reactor having 1.51 void volume, allowed a residence time of $3 \mathrm{~h}$ and then filtered through a four-layered filter. Figure 3 shows the results. The effluent $\left[\mathrm{F}^{-}\right]$was within the acceptable range until breakthrough was observed after 250 batches. This means 831 of defluoridated water was achieved per kilogram of limestone. The final $\mathrm{pH}$ of treated water was found to be in the range between 7.10 and 7.70 after passing through the four-layered filter.

\section{Field trial}

Performance of the small community field unit: For easy acceptability by the local users, the present fluoride removal method was named as Fluoride Nilogon. Figure 4 shows the results of fluoride removal and final $\mathrm{pH}$ of the water after removal of fluoride using the optimized dose of $0.68 \mathrm{mM}[\mathrm{PA}]_{0}(102 \mathrm{ml}$ of $8.5 \%$ PA in 2201 water) in the small community Fluoride Nilogon unit installed at Dengaon, Karbi Anglong district, on 15 March 2013. The effluent $\left[\mathrm{F}^{-}\right]$is consistent within $0.6-0.7 \mathrm{mg} / \mathrm{l}$ up to 579 batches in over $5 \frac{1}{2}$ years, showing no signs of depletion of the limestone till date. The small community field unit has been showing remarkably better performance than the replica unit in the laboratory. It may be noted here that we used crushed limestone chips of size $10-15 \mathrm{~mm}$ in the replica unit test in the laboratory. Since it was impractical to choose such a narrow size range of chips for large quantities of limestone, chip sizes of 1-20 mm were used in the small community field unit. The better performance of the field units compared to the replica unit can be attributed to the presence of smaller chip size of limestone in the small community unit. Decrease in the particle size increases the surface area of limestone, thus increasing the removal of fluoride.

The $\mathrm{pH}$ of the influent field water was 5.89 with $0.68 \mathrm{mM}[\mathrm{PA}]_{0}$. As the water enters the crushed limestone bed reactor, PA is neutralized by limestone ${ }^{38}$. The $\mathrm{pH}$ of the effluent water from the four-layered filter of

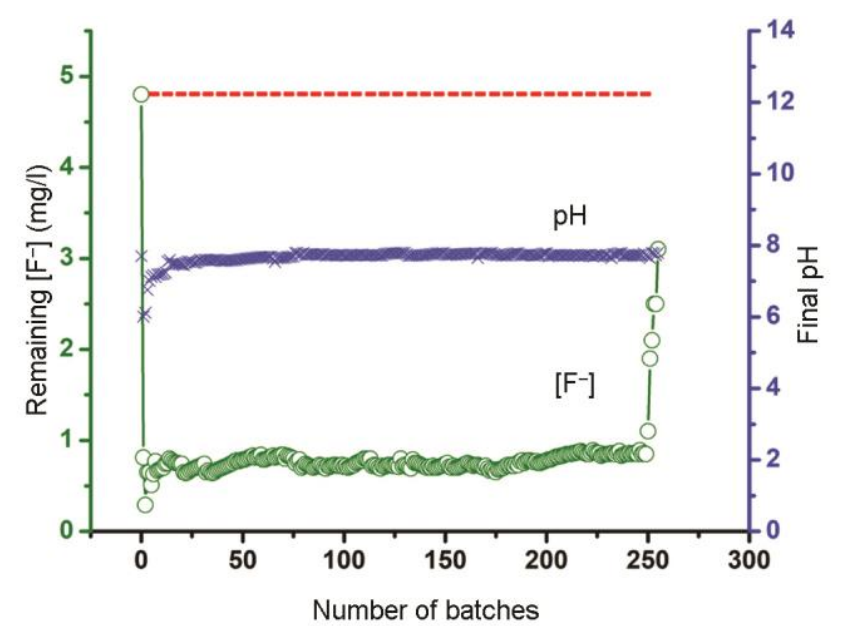

Figure 3. Plots of $\left[\mathrm{F}^{-}\right]$and $\mathrm{pH}$ of treated water versus number of batches for the replica unit $\left[\mathrm{F}^{-}\right]_{0}=4.8 \pm 0.2 \mathrm{mg} / \mathrm{l}$ (broken line), $[\mathrm{PA}]_{0}=0.68 \mathrm{mM}$ and residence time $=3 \mathrm{~h}$.

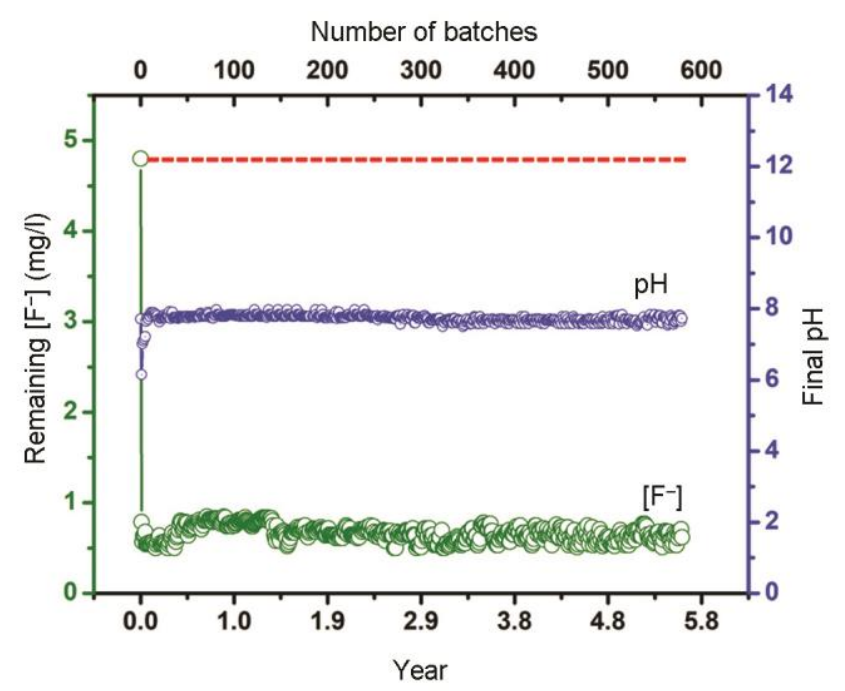

Figure 4. Plots of remaining $\left[\mathrm{F}^{-}\right]$and $\mathrm{pH}$ in treated water versus the number of batches and years of use for the small community field unit. $[\mathrm{F}]_{0}=4.8 \pm 0.2 \mathrm{mg} / \mathrm{l}$ (broken line), $[\mathrm{PA}]_{0}=0.68 \mathrm{mM}$ and residence time $=3 \mathrm{~h}$. 
the small community field unit has been consistently found to be in the range 7.54-7.90, which is acceptable for drinking.

Performance of the household units: Figure 5 and Supplementary Table 1 show the results of the remaining $\left[\mathrm{F}^{-}\right]$ and final $\mathrm{pH}$ of the treated and filtered water for the household Fluoride Nilogon units with 151 pore volume installed at the villages of Napakling (H1), Kehang Inglang (H2), Sarik Teron (H3) and Kat Tisso (H4). The results of another household unit installed in Napakling (H5) by a villager, trained by the present authors at Tezpur University, is also included in the figure. H1 was installed on 12 October 2014, while H2, H3 and H4 were installed on 6 December 2014 and H5 was installed on 15 October 2015. The $\left[\mathrm{F}^{-}\right]_{0}$ in groundwater of the hand tubewell sources of $\mathrm{H} 1, \mathrm{H} 2, \mathrm{H} 3, \mathrm{H} 4$ and $\mathrm{H} 5$ was 5.0, 20, 2.8, 5.2 and $4.2 \mathrm{mg} / \mathrm{l}$ respectively. The procedure followed for operating the household units was the same as that for the small community unit. The dose of PA was $7 \mathrm{ml} 8.5 \%$ PA in 151 water and residence time of water in the reactor was $3 \mathrm{~h}$.

It is interesting to note that the household Fluoride Nilogon units have been showing remaining $\left[\mathrm{F}^{-}\right]$in the range $0.50-0.80 \mathrm{mg} / \mathrm{l}$ consistently till date, for about four years and up to 4625 batches from the time of installation, thus meeting the WHO guideline value, without any sign of exhaustion of the limestone bed (Figure 5). The effluent $\mathrm{pH}$ was in the range 7.4-7.7, which is within the acceptable range $\mathrm{pH}$ for drinking water, i.e. 6.5-8.5. Supplementary Table 1 also shows the average values of effluent $\left[\mathrm{F}^{-}\right]$and $\mathrm{pH}$ obtained from the community and five household systems. The average values were calculated considering all data collected till date. It was observed that in $\mathrm{C} 1, \mathrm{H} 1, \mathrm{H} 2, \mathrm{H} 3, \mathrm{H} 4$ and $\mathrm{H} 5$ units, where

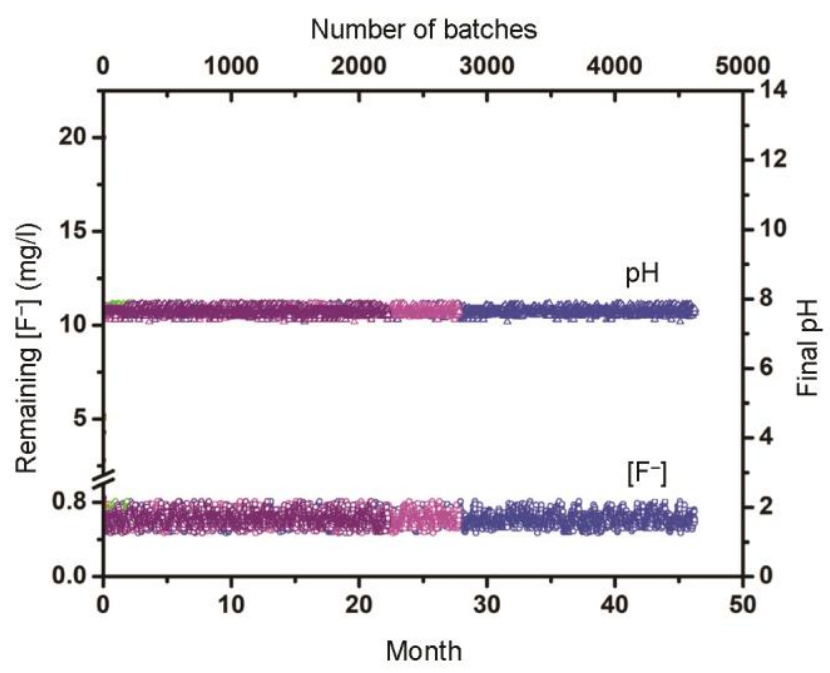

Figure 5. Results of $\left[\mathrm{F}^{-}\right]$before and after treatment along with final $\mathrm{pH}$ versus the number of batches for the household units: H1 (green), $\mathrm{H} 2$ (blue), H3 (magenta), H4 (red) and H5 (purple). $[\mathrm{PA}]_{0}=0.68 \mathrm{mM}$ and residence time $=3 \mathrm{~h}$.
$\left[\mathrm{F}^{-}\right]_{0}$ was $4.8,5.0,20,2.8,5.2$ and $4.2 \mathrm{mg} / 1$ respectively, the average effluent $\left[\mathrm{F}^{-}\right]$was $0.70,0.62,0.59,0.55,0.67$ and $0.62 \mathrm{mg} / \mathrm{l}$ respectively, after treatment. More interestingly, the performance of the present method was found to be independent of initial $\left[\mathrm{F}^{-}\right]_{0}$, at least up to $20 \mathrm{mg} / \mathrm{l}$.

Mechanism of fluoride removal: The observed consistently good fluoride removal without needing any replenishment, regeneration or replacement of the crushed limestone bed for over 4625 batches of use and the method being independent of initial $\left[\mathrm{F}^{-}\right]_{0}$ up to $20 \mathrm{mg} / \mathrm{l}$ may be attributed to the combined precipitationadsorption mechanism of fluoride removal using PACLT $\operatorname{method}^{38}$.

The following reactions have been proposed in the process of fluoride removal by limestone in the presence of $\mathrm{PA}^{38}$.

$$
\begin{aligned}
& \mathrm{CaCO}_{3}(\mathrm{~s})+2 \mathrm{H}_{3} \mathrm{PO}_{4} \\
& \rightarrow \mathrm{Ca}^{2+}+2 \mathrm{H}_{2} \mathrm{PO}_{4}^{-}+\mathrm{CO}_{2}+\mathrm{H}_{2} \mathrm{O}, \\
& \mathrm{CaCO}_{3}(\mathrm{~s})+2 \mathrm{H}_{2} \mathrm{PO}_{4}^{-} \rightarrow \\
& \mathrm{Ca}^{2+}+2 \mathrm{HPO}_{4}^{2-}+\mathrm{CO}_{2}+\mathrm{H}_{2} \mathrm{O}, \\
& \mathrm{Ca}^{2+}+2 \mathrm{~F}^{-} \rightarrow \mathrm{CaF}_{2}(\mathrm{~s}) \downarrow, \\
& \mathrm{Ca}^{2+}+\mathrm{H}_{3} \mathrm{PO}_{4}+2 \mathrm{H}_{2} \mathrm{O} \rightarrow \mathrm{CaHPO}_{4} \cdot 2 \mathrm{H}_{2} \mathrm{O}(\mathrm{s}) \downarrow+2 \mathrm{H}^{+}, \\
& 5 \mathrm{Ca}^{2+}+3 \mathrm{HPO}_{4}^{2-}+3 \mathrm{OH}+\mathrm{F}^{-} \\
& \rightarrow \mathrm{Ca}_{5} \mathrm{~F}\left(\mathrm{PO}_{4}\right)_{3}(\mathrm{~s}) \downarrow+3 \mathrm{H}_{2} \mathrm{O}, \\
& 5 \mathrm{Ca}^{2+}+3 \mathrm{HPO}_{4}^{2-}+4 \mathrm{OH}^{-} \\
& \rightarrow \mathrm{Ca}_{5}(\mathrm{OH})\left(\mathrm{PO}_{4}\right)_{3}(\mathrm{~s}) \downarrow+3 \mathrm{H}_{2} \mathrm{O},
\end{aligned}
$$

$$
\mathrm{Ca}_{5}(\mathrm{OH})\left(\mathrm{PO}_{4}\right)_{3}(\mathrm{~s})+\mathrm{F}^{-} \rightarrow \mathrm{Ca}_{5} \mathrm{~F}\left(\mathrm{PO}_{4}\right)_{3}(\mathrm{~s})+\mathrm{OH}^{-} .
$$

Here, $\mathrm{H}_{2} \mathrm{PO}_{4}^{-}\left(\mathrm{pK}_{\mathrm{a} 2}=7.21\right)$ overshadows $\mathrm{HPO}_{4}^{2-}\left(\mathrm{pK}_{\mathrm{a} 3}=\right.$ 12.35) in the $\mathrm{pH}$ range of treated water. The reactions of dissolution of $\mathrm{CaCO}_{3}$ by the triprotic PA $\left(\mathrm{pK}_{\mathrm{a} 1}=2.12\right)$, eq. (1), the precipitation of $\mathrm{CaF}_{2}$, viz. eq. (3) and the precipitation of FAP and HAP, viz. eq. (4-6) are completed rapidly. Due to this, the fluoride concentration in water comes down to about $2 \mathrm{mg} / \mathrm{l}$ within $3-4 \mathrm{~min}^{38}$. Though FAP has a lower solubility product than that of HAP, high abundance of hydroxide ions in the system makes precipitation of HAP more favourable ${ }^{40}$. The sorption or exchange of the remaining fluoride by HAP (eq. (7)) continues for a longer time as indicated by the continued increase in fluoride removal which lasts for about $3 \mathrm{~h}$ along with some adsorption of fluoride by the renewed limestone surface. Thus, it can be stated that defluoridation takes place predominantly through sorption of fluoride by in situ-formed HAP, in addition to precipitation of $\mathrm{CaF}_{2}$ and FAP. 
The continued consistent performance of the crushed limestone beds in the field units up to 4625 batches of use (Figure 5) is much better compared to the replica unit which showed breakthrough after 250 batches (Figure 3). This can be attributed to the difference in time interval between two consecutive batches in the field compared to that in the replica unit. While the replica unit was used for four batches a day with about 15 min interval between two batches, the field units were used at the most for two batches in a day and that too with at least $9 \mathrm{~h}$ interval between two batches. It is possible that the limestone surface gets enough time to dry and undergo some solidstate reactions increasing porosity or exposure at the surface, which favours dissolution of limestone and subsequent reactions in the next batch. This, however, remains to be verified experimentally. If it is true, along with the fact that the quantity of limestone dissolved by PA $(7 \mathrm{ml}$ $8.5 \% \mathrm{H}_{3} \mathrm{PO}_{4}$ ) per batch of 151 of water, in a household Fluoride Nilogon unit, is $1.53 \mathrm{~g}$ (Supporting Information), the life of the crushed limestone bed of a household Fluoride Nilogon unit may ideally extend to 39,210 batches or 53 plus years. With the field experience till now, this does not seem unlikely.

Plots of average effluent $\left[\mathrm{F}^{-}\right]$versus total alkalinity as $\mathrm{CaCO}_{3}$ of the source water indicate a weak positive correlation between the effluent $\left[\mathrm{F}^{-}\right]$and total alkalinity of the source water with $R^{2}$ of 0.901 (Figure 6). However, there is significantly lesser correlation $\left(R^{2}=0.543\right)$ between the effluent $\mathrm{pH}$ and total alkalinity as $\mathrm{CaCO}_{3}$, except at slightly higher $\mathrm{pH}$ in the case of the small community unit. It may be noted here that the effluent $\mathrm{pH}$ is expected to increase with longer residence time. The effluent water of the small community unit had longer residence time in the filter, which slightly increased the $\mathrm{pH}$.

Potability of treated water: Table 1 presents the relevant water quality parameters before and after treatment

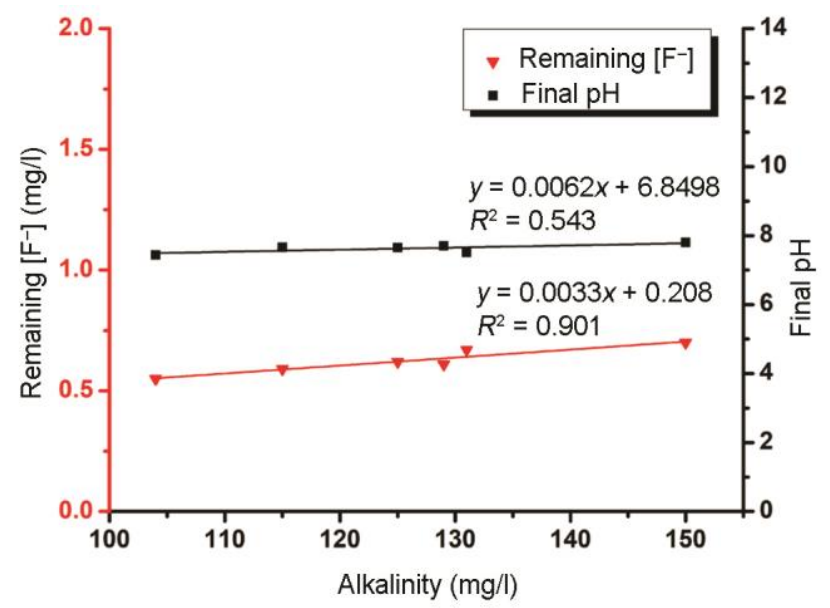

Figure 6. Plots of average value of remaining $\left[\mathrm{F}^{-}\right]$and final $\mathrm{pH}$ of treated water of six field units versus the total alkalinity as $\mathrm{CaCO}_{3}$ of the influent water. measured by standard methods ${ }^{41}$. All the parameters after treatment were within the respective WHO guideline values for drinking water ${ }^{2}$. The concentration of most of the metal ions decreased after treatment, which may be attributed to low solubility of metal phosphates in water. The concentration of $\mathrm{Ca}^{2+}$ and $\mathrm{PO}_{4}^{3-}$ also remained within the WHO guideline values.

\section{Suitability of the method}

Capacity of limestone: Analysis of the composition of the precipitate collected from the bottom of the reactor chamber of the replica unit using a spatula, has shown the presence of HAP, FAP and $\mathrm{CaF}_{2}$, which is consistent with the results reported earlier ${ }^{38}$. The performance of the field units indicates high capacity of limestone in Fluoride Nilogon. However, calculation of the actual capacity is not yet possible as the limestone bed of the community unit has been working consistently for over 579 batches (and 5 $\frac{1 / 2}{2}$ years). Given the field experience, we can assume limestone to work consistently till the entire quantity is dissolved by PA. Considering the use of $7 \mathrm{ml}$ of 8.5\% PA twice a day for a household unit, the total number of batches that will be required to dissolve $60 \mathrm{~kg}$ (the quantity of limestone required to fill a 401 drum) of limestone turns out to be 39,210 . This means that the limestone bed may work up to a maximum of 53.7 years without needing replacement. This estimate is justified as the limestone beds of the household field units have been working consistently over 4625 batches or about four years. Taking the fluoride removed per batch of a household unit as $19.3 \mathrm{mg} / \mathrm{l}$ from the initial $20 \mathrm{mg} / \mathrm{l}$, the estimated capacity of fluoride removal till total exhaustion of the limestone turns out to be $252.2 \mathrm{mg} / \mathrm{g}$. This is incomparable to the capacity of limestone alone $(0.39 \mathrm{mg} / \mathrm{g})^{42}$, activated alumina $(1.08 \mathrm{mg} / \mathrm{g})^{43}$, activated carbon $(1.10 \mathrm{mg} / \mathrm{g})^{44}$, bone char $(1.4 \mathrm{mg} / \mathrm{g})^{45}$ and HAP nanoparticles $(5.5 \mathrm{mg} / \mathrm{g})^{46}$.

Cost estimation: For estimation of the recurring cost incurred in Fluoride Nilogon, one needs to take only the cost of PA into account. The cost of limestone can be included in capital cost as it has almost unlimited lifetime, as mentioned in the previous section. There is no maintenance cost of the units. Thus, considering the market retail price of $85 \% \mathrm{PA}$ as Rs 100 , the recurring cost of the treatment turns out to be Rs 0.00467/1 (USD 0.000063) of treated water, which is much lower than that of $\mathrm{RO}(\approx \mathrm{Rs}$ 0.54 considering Rs 6000 for annual maintenance and 301 water consumption per day) and any adsorptionbased fluoride filters. The capital cost includes only the cost of two plastic containers of desired size, two taps, crushed limestone, sand and gravel. The capital cost turns out to be Rs 600 (USD 8.51) and Rs 4500 (USD 61.12) for the household and small community Fluoride Nilogon units respectively (Supporting Information). 
RESEARCH ARTICLES

Table 1. Relevant water quality parameters before and after treatment by PACLT

\begin{tabular}{lccc}
\hline Parameter $(\mathrm{mg} / \mathrm{l}$ except for $\mathrm{pH})$ & WHO guidelines value & Before treatment & After treatment \\
\hline $\mathrm{pH}$ & $6.50-8.50^{\mathrm{a}}$ & 7.40 & $7.3-7.5$ \\
Dissolved solids & 600 & 175 & 240 \\
Suspended solids & $\mathrm{NS}$ & 12 & 8 \\
Total alkalinity as $\mathrm{CaCO}_{3}$ & 200 & 150 & 154 \\
Total hardness as $\mathrm{CaCO}_{3}$ & 200 & 154 & 160 \\
Phosphate & $\mathrm{NS}$ & 0.135 & 0.109 \\
Sulphate & 500 & 60 & 62 \\
Chloride & 250 & 20 & 7 \\
Nitrate & 50 & 0.45 & 0.27 \\
Cadmium & 0.003 & $<0.001$ & $<0.001$ \\
Calcium & 50 & 10.78 & 12.13 \\
Chromium & 0.05 & $\mathrm{ND}$ & $\mathrm{ND}$ \\
Cobalt & $\mathrm{NS}$ & $\mathrm{ND}$ & $\mathrm{ND}$ \\
Copper & 2.0 & $<1.00$ & $<1.00$ \\
Lead & 0.01 & $<0.001$ & $<0.001$ \\
Magnesium & $\mathrm{NS}$ & 2.81 & 3.40 \\
Manganese & 0.40 & $<0.001$ & $<0.001$ \\
Zinc & 3.0 & 2.5 & 0.07 \\
Sodium & 200 & 94.69 & 85.96 \\
Potassium & $\mathrm{NS}$ & 4.22 & 3.12 \\
Iron & 0.30 & 0.013 & $<0.001$ \\
\hline PAl & $\mathrm{n}$ & \\
\end{tabular}

$[\mathrm{PA}]_{0}=0.68 \mathrm{mM} ;\left[\mathrm{F}^{-}\right]_{0}=4.8 \pm 0.2 \mathrm{mg} / \mathrm{l}$; Source of water sample: piped water supply by PHED.

${ }^{\mathrm{a}}$ Acceptable range for drinking; ${ }^{\mathrm{b}} \mathrm{NS}$, Not specified and ${ }^{\mathrm{c}} \mathrm{ND}$, Not detectable.

Sludge disposal: A toxicity characteristic leaching procedure test prescribed by the United States Environmental Protection Agency (US EPA) was performed on the precipitate produced in the reactor, which showed only $0.35 \mathrm{mg} / \mathrm{l}$ fluoride in the leachate. Thus, leaching from the sludge of Fluoride Nilogon is 429 times lower than the maximum permissible limit of $150 \mathrm{mg} / \mathrm{l}$ allowed for land-fill dumping by US EPA ${ }^{47,48}$. The very low leaching from the sludge may be attributed to the strong binding of $\mathrm{F}^{-}$in FAP. The solid sludge can be easily disposed of in landfills or buried in other safe places like construction sites. However, the question of sludge disposal may not arise now, as the limestone bed is still in a good condition even after 4625 batches of use, and ideally the life of the limestone bed may extend over 53 years.

User satisfaction and present status: Limestone, a lowcost sedimentary rock, is readily available in most of the fluoride-affected areas of the world, including India ${ }^{49}$. In Assam, limestone mines are present in the vicinity of its severely fluoride-affected areas of West Karbi Anglong and Hojai districts. PA is approved by the US EPA for application in water purification ${ }^{47}$. PA is also easily acceptable to people as it is an edible acid used in popular beverages and for preserving packaged food. The treated water does not leave any objectionable odour or colour. Moreover, PA being a weak acid is easy to handle. However, in the present field study, PA has been dispensed to the rural users after ten times dilution from the original strength of $85 \%(\mathrm{~W} / \mathrm{V})$ for further safety.

That the users are satisfied with the Fluoride Nilogon is indicated by continuation of the field trial units by them for over five and half years continuously. There is an increasing desire of the affected people to acquire a household unit of their own. Government restrictions on procurement of limestone are however a great deterrent faced by the villagers. Despite that, there are six small community and 35 household Fluoride Nilogon units at present in West Karbi Anglong district, most of which have been installed by trained local people. With involvement of various individuals and government and non-governmental organizations, e.g. Karbi Anglong Autonomous Council, National Programme for Prevention and Control of Fluorosis, and Art of Living, Fluoride Nilogon is set for implementation in a big way soon in Karbi Anglong.

\section{Conclusion}

The present field study proves that Fluoride Nilogon, is a good rural technology for fluoride removal. The method involves pre-mixing of fluoride-contaminated water with a dose of $0.463 \mathrm{ml}$ of $8.5 \% \mathrm{PA} / 1$ of water to give a concentration of $0.68 \mathrm{mM}$ of PA in water, subsequent treatment of the water in a fixed-bed crushed limestone reactor of chip size $1-20 \mathrm{~mm}$ for $3 \mathrm{~h}$, and then sandgravel filtration. The crushed limestone bed needs to be pretreated with $0.01 \mathrm{M}$ PA. The method removes excess fluoride efficiently from as high as $20 \mathrm{mg} / \mathrm{l}$ to a desired level of $0.7 \mathrm{mg} / \mathrm{l}$. The removal is independent of the initial $\left[\mathrm{F}^{-}\right]$and a higher dose of PA can totally remove fluoride. The $\mathrm{pH}$ of the treated water remains within 7.47.9 , which is in the middle of the acceptable range of 
6.5-8.5 for drinking. All other relevant water quality parameters for the treated water remain within the guideline values of WHO.

The field units have been working consistently over 4625 batches or $5 \frac{1}{2} 2$ years without needing any interventions like regeneration, replenishment or replacement of the limestone. The estimated life of the crushed limestone bed of a household Fluoride Nilogon unit used twice a day with $20 \mathrm{mg} / \mathrm{l}$ feed water is 39,210 batches or over 50 years. The recurring cost of the treatment which includes only the cost of PA is Rs 0.00467 (USD 0.000063)/l of treated water. This is much lower than any other fluoride removal methods. Requiring only two containers, two taps, limestone, sand and gravel, the capital cost of 151 household and 2201 small community Fluoride Nilogon units is only Rs 600 (USD 8.51) and Rs 4500 (USD 61.12) respectively. Finally, it can be concluded from the present field experience that, high efficiency, high capacity of limestone, extremely low cost, safe, environment-friendliness, non-requirement of electricity, nonrequirement of regeneration, replenishment or replacement of any part for years (possibly decades), simple enough to be operated by a layman and user satisfaction prove Fluoride Nilogon as a good rural technology to address the worldwide problem of excess fluoride in drinking water.

1. Susheela, A. K., A treatise on fluorosis. Fluorosis Research and Rural Development Foundation, New Delhi, 2001.

2. WHO, Guidelines for Drinking-Water Quality, Geneva, World Health Organization, 2011, 4th edn, pp. 370-371.

3. Swarup, D. and Dwivedi, S. K., Environmental pollution and effects of lead and fluoride on animal health, Indian Council of Agricultural Research, New Delhi, 2002.

4. Edmunds, M. and Smedley, P., Fluoride in natural waters. In Essentials of Medical Geology, Impacts of Natural Environment on Public Health, Elsevier Academic Press, London, UK, 2005.

5. Ali, S., Thakur, S. K., Sarkar, A. and Shekhar, S., Worldwide contamination of water by fluoride. Environ. Chem. Lett., 2016, 14, 291-315.

6. Dutta, R. K., Saikia, G., Das, B., Bezbaruah, C., Das, H. B. and Dube, S. N., Fluoride contamination in groundwater of central Assam, India. Asian J. Water Environ. Pollut., 2006, 2, 93-100.

7. Das, B., Talukdar, J., Sarma, S., Gohain, B., Dutta, R. K., Das, H. B. and Das, S. C., Fluoride and other inorganic constituents in groundwater of Guwahati, Assam, India. Curr. Sci., 2003, 85, 657-661.

8. BIS, Indian Standard Specification for Drinking Water, IS 10500 , Bureau of Indian Standards, New Delhi, 1991, pp. 2-4.

9. Mohapatra, M., Anand, S., Mishra, B. K., Giles, D. E. and Singh, P., Review of fluoride removal from drinking water. J. Environ. Manage., 2009, 91, 67-77.

10. Maheshwari, R. C., Fluoride in drinking water and its removal. J. Hazard. Mater., 2006, 137, 456-463.

11. Bhatnagar, A., Kumar, E. and Sillanpaa, M., Fluoride removal from water by adsorption - a review. Chem. Eng. J., 2011, 171, 811-840.

12. Nawlakhe, W. G., Kulkarni, D. N., Pathak, B. N. and Bulusu, K. R., Defluoridation using the Nalgonda technique in Tanzania. Indian J. Environ. Health, 1975, 17, 26-65.
13. Ndiayea, P. I., Moulin, P., Dominguez, L., Millet, J. C. and Charbit, F., Removal of fluoride from electronic industrial effluent by RO membrane separation. Desalination, 2005, 173, 25-32.

14. Vasudevan, S., Lakshmi, J. and Sozhan, G., Studies on a Mg-Al$\mathrm{Zn}$ alloy as an anode for the removal of fluoride from drinking water in an electrocoagulation process. Clean-Soil Air Water, 2009, 37, 372-378.

15. Lhassani, A., Rumeau, M., Benjelloun, D. and Pontie, M., Selective demineralization of water by nanofiltration application to the defluorination of brackish water. Water Res., 2001, 35, 3260 3264.

16. Viswanathan, N. and Meenakshi, S., Selective fluoride adsorption by a hydrotalcite/chitosan composite. Appl. Clay Sci., 2010, 48, 607-611.

17. Meenakshi, S. and Viswanathan, N., Identification of selective ion-exchange resin for fluoride sorption. J. Colloid Interface Sci., 2007, 308, 438-450.

18. Wang, J., Kang, D., Yu, X., Ge, M. and Chen, Y., Synthesis and characterization of $\mathrm{Mg}-\mathrm{Fe}-\mathrm{La}$ trimetal composite as an adsorbent for fluoride removal. Chem. Eng. J., 2015, 264, 506-513.

19. Fan, X., Parker, D. J. and Smith, M. D., Adsorption kinetics of fluoride on low cost materials. Water Res., 2003, 37, 49294937.

20. Turner, B. D., Binning, P. and Stipp, S. L. S., Fluoride removal by calcite: evidence for fluorite precipitation and surface adsorption. Environ. Sci. Technol., 2005, 39, 9561-9568.

21. Murutu, C., Onyango, M. S., Ochieng, A. and Otieno, F. A. O., Fluoride removal performance of phosphoric acid treated lime: breakthrough analysis and point-of-use system performance. $W a$ ter $S A, 2012$, 38, 279-285.

22. Thole, B., Mtalo, F. and Masamba, W., Groundwater defluoridation with raw bauxite, gypsum, magnesite, and their composites. Clean-Soil Air Water, 2012, 40, 1222-1228.

23. Mourabet, M., El Boujaady, H., El Rhilassi, A., Ramdane, H., Bennani-Ziatni, M., El Hamri, R. and Taitai, A., Defluoridation of water using brushite: equilibrium, kinetic and thermodynamic studies. Desalination, 2011, 278, 1-9.

24. Maiti, A., Basu, J. K. and De, S., Chemical treated laterite as promising fluoride adsorbent for aqueous system and kinetic modeling. Desalination, 2011, 265, 28-36.

25. Asgari, G., Roshani, B. and Ghanizadeh, G., The investigation of kinetic and isotherm of fluoride adsorption onto functionalize pumice stone. J. Hazard. Mater., 2012, 217, 123-132.

26. Raichur, A. M. and Basu, M. J., Adsorption of fluoride onto mixed rare earth oxides. Sep. Purif. Technol., 2001, 24, 121-127.

27. Li, Y. H. et al., Adsorption of fluoride from aqueous solution by graphene. J. Colloid Interf. Sci., 2011, 363, 348-354.

28. Huang, R. H., Yang, B. C., Liu, Q. and Ding, K. L., Removal of fluoride ions from aqueous solutions using protonated cross-linked chitosan particles. J. Fluorine Chem., 2012, 141, 29-34.

29. Lounici, H., Addour, L., Belhocine, D., Grib, H., Nicolas, S., Bariou, B. and Mameri, N., Study of a new technique for fluoride removal from water. Desalination, 1997, 114, 241-251.

30. Nigussie, W., Zewge, F. and Chandravanshi, B. S., Removal of excess fluoride from water using waste residue from alum manufacturing process. J. Hazard. Mater., 2007, 147, 954-963.

31. Murutu, C. S., Onyango, M. S., Ochieng, A. and Otieno, F. A., Investigation on limestone derived apatite as a potential low cost adsorbent for drinking water defluoridation; http://www.Ewisa.Co. Za/literature/files/148 101\%20murutu.Pdf (accessed on 10 October 2018)

32. Reardon, E. J. and Wang, Y., A limestone reactor for fluoride removal from wastewaters. Environ. Sci. Technol., 2000, 34, 3247-3253.

33. Gogoi, S. and Dutta, R. K., Mechanism of fluoride removal by phosphoric acid-enhanced limestone: equilibrium and kinetics of fluoride sorption. Desalin. Water Treat., 2016, 57, 6838-6851. 
34. Nath, S. K. and Dutta, R. K., Enhancement of limestone defluoridation of water by acetic and citric acids in fixed bed reactor. Clean-Soil Air Water, 2010, 38, 614-622.

35. Nath, S. K. and Dutta, R. K., Fluoride removal from water using crushed limestone. Indian J. Chem. Technol., 2010, 17, 120 125

36. Nath, S. K. and Dutta, R. K., Acid-enhanced limestone defluoridation in column reactor using oxalic acid. Process Saf. Environ. Prot., 2012, 90, 65-75.

37. Nasr, A. B., Walha, K., Puel, F., Mangin, D., Amar, R. B. and Charcosset, C., Precipitation and adsorption during fluoride removal from water by calcite in the presence of acetic acid. Desalin. Water Treat. Prot., 2014, 52, 2231-2240.

38. Gogoi, S., Nath, S. K., Bordoloi, S. and Dutta, R. K., Fluoride removal from groundwater by limestone treatment in presence of phosphoric acid. J. Environ. Manage., 2015, 152, 132-139.

39. Dutta, R. K. and Nath, S. K., A highly efficient defluoridation method by in situ generation of an efficient precipitant and strong adsorbents of fluoride in crushed limestone fixed-bed column and plug flow reactors. Indian Patent No. 2892204, 2017.

40. Narasaraju, T. S. B. and Rai, U. S., Some thermodynamic aspects of dissolution of solid solutions of hydroxylapatites of phosphorus and arsenic. Can. J. Chem., 1979, 57, 2662-2664.

41. APHA, Standard Methods for the Examination of Water and Wastewater, American Public Health Association, New York, USA, 17th edn, 1998.

42. Biswas, K., Gupta, K. and Ghosh, U. C., Adsorption of fluoride by hydrous iron(iii)-tin(iv) bimetal mixed oxide from the aqueous solutions. Chem. Eng. J., 2009, 149, 196-206.

43. Maliyekkal, S. M., Sharma, A. K. and Philip, L., Manganese oxide-coated alumina: a promising sorbent for defluoridation of water. Water Res., 2006, 40, 3497-3506.
44. Ramos, R. L., Ovalle-Turrubiartes, J. and Sanchez-Castillo, M. A. Adsorption of fluoride from aqueous solution on aluminumimpregnated carbon. Carbon, 1999, 37, 609-617.

45. Dahi, E. and Nielsen, J. M., In Proceedings of the 2nd International Workshop on Fluorosis Prevention and Defluoridation of Water, Ethiopia, 19-25 November 1997.

46. Poinern, G. E. J., Ghosh, M. K., Ng, Y. J., Issa, T. B., Anand, S. and Singh, P., Defluoridation behavior of nanostructured hydroxyapatite synthesized through an ultrasonic and microwave combined technique. J. Hazard. Mater., 2011, 185, 29-37.

47. http://www.Epa.Gov/osw/hazard/wastetypes/wasteid/inorchem/docs/ phosphor.pdf

48. US EPA, Method 1311: Toxicity characteristic leaching procedure, US Environmental Protection Agency, Washington, DC, 1992.

49. Nath, S. K. and Dutta, R. K., Significance of calcium containing materials for defluoridation of water: a review. Desalin. Water Treat., 2015, 53, 2070-2085.

ACKNOWLEDGEMENTS. We thank Bokajan Cement Factory of Cement Corporation of India, Bokajan, Assam, for gifts of several tonnes of limestone and the Department of Science and Technology (Water Technology Initiative), New Delhi for financial support (DST/TM/WTI/2K16/95 dated 15/6/2017). Deneb Instruments, Kolkata gifted us a Fluoride ISE. S. G. and S. B. thank CSIR, New Delhi for SRF fellowships. R. M. and A. J. B. thank Tezpur University for institutional fellowships. We are grateful to the users for their interest and cooperation. R. K. D. thanks his friends who extended a helping hand, including financial support, in the field trial.

Received 5 October 2018; revised accepted 17 September 2019

doi: $10.18520 / \mathrm{cs} / \mathrm{v} 118 / \mathrm{i} 2 / 255-263$ 